\title{
Human Capital Need in Islamic Finance Education: A
}

\section{Case of Australia}

\author{
M. Ishaq Bhatti \\ Department of Finance \\ La Trobe Business School, La Trobe University, Melbourne, Australia, \\ \& King Abdulaziz University, Saudi Arabia*
}

\begin{abstract}
Accepted: September 28, 2012 Published: November 24, 2012
Doi:10.5296/ijld.v2i6.2753 URL: http://dx.doi.org/10.5296/ijld.v2i6.2753
\end{abstract}

\begin{abstract}
The main objective of this paper is to demonstrate training requirement for human capital needed in the emerging field of Islamic Finance (IF) industry in Australisian region. It proposes the structure of the curriculum which can build bridges among multi-culture/faith communities based on sound understanding of finance and Shariah in the western democratic societies where Muslims are in minorities. It presents a case study of La Trobe University's pioneering Master of Islamic Banking and Finance (MIBF) degree structure and an online six week's e-learning short course on Islamic Finance Professional Development (IFPD) jointly with Ethica Institute in UAE. The course is then linked with various components of the professional bodies, like Masters' in professional accounting (MPA), financial analysis (MFA), and MBA (restricted to electives only), CFA, GARP and then extension to PhD level education in IF. The paper addresses various aspects of IF education such as the significance of knowledge, curriculum design, procedures in acquiring support from within the University academic community, challenges in marketing the course and the needed research backing. It also reviews some illustrating statistics to support the need for the course in Australasian region and highlight statistical finding of our MIBF alumni. The paper closes with final remarks and recommendations to industry and policy makers.
\end{abstract}

Acknowledgement: Many thanks to Dr K. Al-Shauibi and M. Al-Habib, Associate Dean, College of Economics and Administrative Sciences in facilitating to finalise this work at King Abdulaziz University (KAU). Some contents of the paper is appearing as a chapter 10 in the Book entitled, "Islamic Finance in Western Higher Education: 
Developments and Prospects", Edited by C. Trullols, A. Belouafi and A. Belabes, Saudi Spanish Centre of Islamic Economics and Finance, Madrid, Palgrave Macmillan publisher, $U K \&$ Islamic Economic Institute, KAU. I would also, like to thank Mary Imam, Maria Bhatti for constructive comments on an earlier version of this paper and to Phong Nguyen for his excellent research assistantship.

\section{Introduction}

Australia is the fourth largest investment fund holder in the world. Australia has one of the strongest resources based economy among all developed and OECD countries. Due to its geo-political location, Australia's neighbouring countries include highly populated Muslim countries. Australia's structured and solid economy can serve well to train needed human capital for the rapidly emerging area of Islamic Finance (IF). Australia's education is the third largest export earning following mining. Due to solid education export base in conventional finance (CF), Australia can be a leader in IF and Shariah based financial regulatory education hub in the region. There are a limited number of educational institutions providing IF and CF mix of training to cater the needs of the global IF industry. Only those who can tap into sophisticated computing technologies and the develop new courses which can build bridges between multidisciplinary areas to meet the needs of the ever expanding and complex financial management industry based on high speed cloud computing facilities.

According to Kearney (2006), the finance industry will require more than 30, 000 IF experts $^{1}$ only in the Gulf region in the next decade if the growth rate in IF continues at the current rate. At the moment, the expected growth rate in IF is approximately $15 \%$ annually ${ }^{2}$, resulting in a rapidly growing need for highly qualified IF experts who can work in the industry with innovative products to earn a living for the investors and themselves. Currently, IF is around $2 \%$ of the total CF implying that the volume of transactions, investment, liquidity and accounts activities in the IF industry is still lower compared to CF. However, its future growth prospects are promising if it can successfully offer financial alternatives to investors and international firms and banks in context of sophisticated products which can accommodate the needs of the ever growing Muslim population looking for halal financial services.

\footnotetext{
${ }^{1}$ Kearney, A. T. (2006), Booming Islamic banking will need 30,000 jobs in the Gulf in 10 years, AMEinfo, http://www.ameinfo.com/106063.html

${ }^{2}$ Perry, Frederick; Rehman, Scheherazade, “Globalization of Islamic Finance: Myth or Reality?”, International Journal of Humanities and Social Science, Vol.1, No.9, December 2011.
} 
The main objective of this paper is to demonstrate how to structure an innovative course which can provide needed training to create human capital for the IF industry in the western world where Muslims are in minority. This paper proposes the structure of an IF curriculum which can build bridges among multi-culture/faith communities based on sound understanding of finance and Shariah. It presents a successful case study of La Trobe University (LTU)'s pioneering Master of Islamic Banking and Finance (MIBF) degree structure and an online course on Islamic Finance Professional Development (IFPD) with links into MIBF, MBA (restricted electives) and then to $\mathrm{PhD}$ level education in IF. This develops a general mould in this teaching practice that can integrate IF and CF. This paper also addresses various aspects of IF education such as the significance of knowledge, curriculum design, procedures in acquiring support from within the University academic community, challenges in marketing the course and the needed research backing. It also reviews some illustrating statistics to support the need for the course in Australasian region.

The structure of the rest of this paper is as follows. The next section presents the motivation for IF education globally as well as in Australia. It demonstrates that the driving force behind the growth of IF is the Muslim population growth. It explains about the structure of the course. Section 3 concentrates on the rationale, marketing as aspects, and curricula design of various IF and Islamic Banking (IB) courses being offered at La Trobe. Section 4 explains the recruitment of students and their classroom experience, graduation process and then finally job seeking internships and career development in various areas of finance. The final section of the paper contains some concluding remarks.

\section{Contemporary Islamic Finance in the World}

The concept of IF has arisen from a requirement for interest-free finance in the 1940s in Malaysia and in the late 1950s in Pakistan. The first officially accredited Islamic financial institution, Muslim Pilgrims Savings Corporation, was founded in Malaysia in 1963. That was followed by a series of institutional and banking establishments in Middle East, Africa and Southeast Asia. A significant milestone in IF history took place after forming of the Organization of Islamic Conference $(\mathrm{OIC})^{3}$ and the associated financial institution, the Islamic

\footnotetext{
${ }^{3}$ OIC is an inter-governmental organization grouping fifty-seven (57) States. They decided to pool their resources together, combine their efforts and speak with one voice to safeguard the interest and ensure the progress and well-being of their peoples and those of other Muslims in the world over. It was established in Rabat, Morocco, on 25 September 1969. Member countries are; Afghanistan, Albania, Algeria, Azerbaijan, Bahrain, Bangladesh, Benin, Brunei, Burkina-Faso, Cameroon, Chad, Comoros, Cote d'Ivoire, Djibouti, Egypt, Gabon, Gambia, Guinea, Guinea-Bissau, Guyana, Indonesia, Iran, Iraq, Jordan, Kazakhstan, Kuwait, Kyrgyzstan, Lebanon, Libya, Malaysia, Maldives, Mali, Mauritania, Morocco, Mozambique, Niger,
} 
Development Bank (IDB) ${ }^{4}$. These institutions are seen as the official international associations to govern and foster Islamic financial transactions around the world. These organizations have contributed to the success of the IF industry to its current average growth level between $15 \%$ to $20 \%$. However, the total assets of the ten largest Muslim nations are just equivalent to approximately $2.7 \%$ of the global GDP ${ }^{5}$. It is still a tiny number which indicates the infancy status of the IF industry. The modern challenges to IF industry are the shortage of standardization regulations and practices and Muslim-styled finance countries, but also among the Islamic countries with different interpretations of Shariah principles. Moreover, the isolation of investors around the globe who have been only familiar with CF for a long time is also a considerable obstacle (Khan and Bhatti (2008)).

All of the reasons above illustrate an essential demand for a basic and complete institution that can raise awareness in investors and bring standardization to the global financial environment in which Islamic financial services and products can emerge to contribute to the diversification of investments.

\subsection{Islamic Finance in Australia}

In Australia, the Muslim community is expanding with the second fastest growth rate of $40.2 \%$ compared to Christianity which are numbering over 500,000 individuals $(2.3 \%)$ approximately over 100,000 households. The majority of the community is young with half of the population is below 24 years of age. This growth creates a crucial need for a financial industry which is based on Islamic principles. A prominent financial institution with retail services in this respect is Muslim Community Corporation of Australia (MCCA), which is trying to become the first Australian Islamic bank to provide retail services to the communities in Melbourne and Sydney. According to MCCA News number 1, 2012, MCCA will achieve \$1 billion in Islamic financing by 2015. Meanwhile, all over the world, Western conventional banks such as HSBC, Lloyds TSB, Citibank, ABN AMRO, Deutsche Bank, Standard Chartered and JP Morgan have established Islamic banking subsidiaries called 'Islamic windows'. Specifically during the last few years, Australia has seen the establishment of Kuwait Finance House (KFH), Westpac's commodity-trading facility, Crescent Wealth which

\footnotetext{
Nigeria, Oman, Pakistan, Palestine, Qatar, Saudi Arabia, Senegal, Sierra Leone, Somalia, Sudan, Suriname, Syria, Tajikistan, Togo, Tunisia, Turkey, Turkmenistan, Uganda, United Arab Emirates, Uzbekistan, and Yemen.

${ }^{4}$ IDB is an international financial institution established in December 1973 with main purpose to foster the economic development and social progress of 57 member countries of OIC and Muslim communities individually as well as jointly in accordance with the principles of Shariah i.e., Islamic Law. The functions of the IDB are to participate in equity capital, grant loans for productive projects and enterprises besides providing financial assistance to member countries for economic and social development. The Bank is authorized to accept deposits and to mobilize financial resources through Shariah compatible modes. Source: http://www.isdb.org/.

${ }^{5}$ World Bank Data, (World Development Indicators), Washington D.C, 2006
} 
launched the first Shariah compliant equity fund, ANZ's investment in AmBank, NAB's operations in sukuk and the growing intentions of HSBC Amanah to compete down under ${ }^{6}$. In light of this activity, an official authority has been establish by Australian Financial Markets Association (AFMA) as an Islamic banking and finance working group that is operating closely with the Treasury to facilitate Islamic banking and finance in Australia. Australian Government can see the additive advantages of IF in various industries, like agriculture, mineral resources and infrastructure advances, the Islamic financial products related to commodities can flourish and re-enforce the position of Australia as a global leader and innovator in public and private infrastructure complex financing. Moreover, continued growth in major Asian economies can be expected to increase the need for developing resources-related services and infrastructure, which are ideal assets for different modes of Islamic financing, such as Sukuk, Mudaraba, Murabaha and Ijarah ${ }^{7}$.

Australia is well-positioned to structure and offer such instruments as a part of financing packages for resources-related development. There is also a crucial focus in the national strategy on Australia's ambition to be an Asia Pacific financial centre. However, to be successful Australia must train and produce a generation of IF scholars who are able to comprehend the Shariah compliant products as well as having an intensive knowledge about the current global financial environment. The industry requires a standardized and well-established IF education system in the world and especially in Australia due to its leadership role in delivering quality higher education and research training in the region.

\subsection{Islamic Finance Education}

In response to the significant growth of Islamic Banking and Finance, some educational training courses and degree programmes have been designed by various agencies and the universities in the US and UK, GCC and Asia Pacific region to supply a basic knowledge to investors and students. However, there are still no internationally standardized curricula for these programmes. To date academic training in IF has been delivered by mixed offering, face to face and distance learning modes. These can be based on short courses, (diplomas, professional qualifications) and degrees (undergraduate and postgraduate) coursework and

\footnotetext{
${ }^{6}$ Colan, Almir, Principles of Islamic Finance, MCCA News, Number 1, March 2012. Almir graduated from La Trobe in 2011, he is an advisor to MCCA and the founder of AusCif (Australian centre for Islamic Finance). He teaches Islamic Finance Professional Development (IFPD) course at La Trobe.

${ }^{7}$ Austrade, Islamic Finance, 2010,

http://www.austrade.gov.au/search.aspx?articleid=4345\&moduleid=8367\&keywords=islamic\%20finance\&sitesection=\&site sectiondescr $=$
} 
research degrees ${ }^{8}$. The first two result in a wide range of certificates and postgraduate diplomas. The online program is usually based on four modules that cover Islamic economics, financial instruments, banking and Takaful. In addition, there are many short courses related to contract law in Islam and Islamic law including AusCif short courses and LTU's IFPD.

Research degree programs dominate the landscape in Australia (La Trobe only), Europe and North America. The Harvard IF Project, the establishment of a chair in IF at Rice University, the Master degree in Islamic Economics and Finance at Loughborough University, Leicester, UK, the MA and MSc programmes in IF at Durham University, UK, and the MA in Islamic Management, Banking and Finance at Markfield Institute of Higher Education, Leicester, UK are all examples of a growing stress on intellectual exactitude. This category is rounded up by the Islamic Economics Research Institute at King Abdulaziz University in Jeddah, Saudi Arabia and the Masters Programs with Islamic Orientation at the International Islamic Universities in Bangladesh, Malaysia, Pakistan and Sudan.

However, there is a lack of international standards in these programs with some exception. Literature review revealed almost none of these courses are accredited with professional bodies, the way CF is. So the quality of graduates filling up IF positions are poorer compared to CF graduates. Therefore, an academic standardization needs to be established and accepted to offer degrees which can be recognized and accepted by relative accredited professional bodies and industries. In Australia, the education services sector, is a significant contributor to the GDP and was Australia's third largest export between 2006 and 2008. The latest ranking of Australia's top exports of goods and services shows education services ranked fourth in 2008-09, followed by coal, iron and gold. In spite of being home to less than one percent of the world's population, Australia attracts 7.5 percent of the world's foreign students ${ }^{9}$. The majority of these students are Muslims from South East Asia including China, the Indian sub-continent, Malaysia, Hong Kong, Vietnam, Singapore and Middle East and North Africa's oil rich countries.

Australia has the opportunity to combine its ambition to be a strategic financial hub in Asia Pacific region with its reputation as a significant player in the world education services sector to develop its financial services education capacity and its educational partnerships with

\footnotetext{
${ }^{8}$ Chowdhry, Sajjad, "An Introductory Review of the major centers and initiatives for Islamic finance education around the world”, Dinar Standard, http://www.dinarstandard.com/finance/finance_instit120604.htm, Jun 2010

${ }^{9}$ Khalid Kocer, 2009, The Global Financial Crisis and International Migration: Policy Implications for Australia, Lowy Institute for International Policy, July 2009, p. 4
} 
the region to set the standard and provide the human resources required for an IF industry in Australasian region. In light of this, La Trobe University launched its Masters of Islamic Banking and Finance (MIBF) programme on 6 July 2009. The event was launched by then the Federal Minister of financial services and superannuation (small Business Minister in 2012). He appreciated that this is the first course in Australia dedicated to training in Islamic banking and finance. Since 2009 the course has provided students with postgraduate training in the technical skills demanded by Islamic capital markets and institutions all over the world. The curriculum has been specifically developed to appeal to the international students around the world, especially those from Asia-Pacific, Middle East and other Muslim minority countries, who would like to acquire Islamic financial training in English as well as to local students who are keen to develop their careers in this IF industry.

In addition, an online course, namely the IFPD was designed and launched in January 2011 to fulfil the interest of students, government employees working in finance areas, bankers, financiers and other audiences who want to stay current with developments in the banking industry and especially the development of IF. The rest of the paper aims to describe the La Trobe program in terms of good educational practice that establishes a standard in Australia and around the world for the provision of expert knowledge on the operation of IF globally.

\section{Islamic Finance Courses at La Trobe}

\subsection{Master of Islamic Banking and Finance (MIBF)}

\subsubsection{Rationale of the MIBF course}

The MIBF is an unprecedented full-time course-work master program in Australia. MIBF is designed to cater for the demand of postgraduates with academic knowledge and practical skills in a variety of subjects such as Islamic Banking, Insurance, Commercial Law, Capital Markets of IF industry. The course has been designed to be suitable for international students as well as local students who are interested in learning and developing the existing IF industry. As stated by founding Director ${ }^{10}$ of Islamic Finance programme at La Trobe University, "the most attractive and advanced quality of MIBF is integration of IF with CF and banking perspectives which is consistent with Shariah principles as set out in Qu'ran." The academic quality of the program is further enhanced by its ties to the CFA program. This allows participants of the course to be well prepared as new financial products related to IF emerge in

\footnotetext{
${ }^{10}$ Dr M. Ishaq Bhati: Associate Professor in the Department of Finance, La Trobe Business School, at La Trobe University, Melbourne, Australia.
} 
the CF markets. Through this program, La Trobe University seeks to bridge a shortage of IF academy to provide a well-equipped experts and technical professionals in Australia. The course supports the national strategy to foster and develop IF in Australia and is one element of the goal of making the country a financial hub in Asia Pacific region.

The academy of the course has been recognized by the International Centre of Education in Islamic Finance (INCEIF) based in Malaysia in 2009 by signing 3 years memorandum of understanding (MOU) for cooperation between the two institutions. The successful graduates with MIBF are entitled to participate in Chartered Islamic Finance Professional (CIFP) ${ }^{11}$ part 1 exams subject to passing their all the exam requirements. Moreover, Indonesian's Trisakti University also accredit our MIBF students to their accredited qualifications via MOU and continuous mutual research and students exchange and training programme. Recent example of such collaboration is November 2012, when Trisakti students visited La Trobe and Australian. Beside other collaborative programmes, La Trobe was also involved in training Iraqi central Bankers in 2010 via AusTraing project, IDB's Islamic Research and Training Institute event in Turkey, European Business School in Paris and MOU with Nizwa University in Oman. Moreover, La Trobe is a globally recognized University and its degree and certification recognised in global finance industries, IF certifications bodies in the Middle East, South East Asia, Gulf Cooperation Countries (GCC), Malaysia, and Indonesia where there is still an academic gap in IF service training.

The strength of MIBF is the curriculum which is industry-driven by consultancy of industry experts as well as renowned academic staff. In addition, the course puts a strong emphasis on foundation units focusing on economics, finance, quantitative analysis methods and accounting based on CFA curriculum and text books that result in multi-dimensional understanding about theory and operation of IF in practice.

\subsubsection{Target audience}

There are currently more than 300 Islamic financial institutions ${ }^{12}$ around the world with three organizations based in Melbourne. These institutions serve a growing Muslim population, and their continued growth depends on academic and technical human resource which can cover principles, operation and mechanism of the currently dynamic Islamic capital market and finance industry. MIBF is to provide graduates with an understanding of various products and process in the IF industry along with accreditation and linkages with the FINSIA

\footnotetext{
${ }^{11}$ INCEIF's CIFP is industry-based certificate initiated by Malaysian Central Bank; Bank Negara Malaysia

${ }^{12}$ Global Finance, World Best Islamic Financial Institutions 2011,

http://www.gfmag.com/tools/best-banks/11198-worlds-best-islamic-financial-institutions-2011.html\#axzz1vO6LR3a2
} 
(Financial Institute of Australia), CFA, CIFP, Indonesia, Paris and Ethica, Dubai's accreditations. The audiences for the course can be put into three categories.

a) - Financiers and bankers who seek specialized knowledge of a newly rising market and academic recognition for their own professional development. As specialists in IF in a Western banks, this groups enhances their career opportunities..

b) - Academic researchers and CF experts who wish achieve advanced IF knowledge and study new aspect in the phenomenon.

c) - Investors who wish to enhance their awareness about a rising market in order to improve portfolio diversification with modern IF products.

\subsubsection{Curricula design}

Due to the needs of the various target audiences, the curriculum of the course is a mix between discipline specific lectures and class activities, which provide academic understanding about techniques and operation in IF. The course provides opportunities for internship activities and incorporates guest speakers from both CF and IF, which bring practical experience regarding industry mechanisms. The curriculum in MIBF was created with the objective to develop an advanced knowledge in the field of economics, finance and complicated working mechanism of IF including its legal and regulatory framework and Shariah compliancy process in Australia and abroad. Throughout the course, students are exposed to the five key principles which underlie IF:

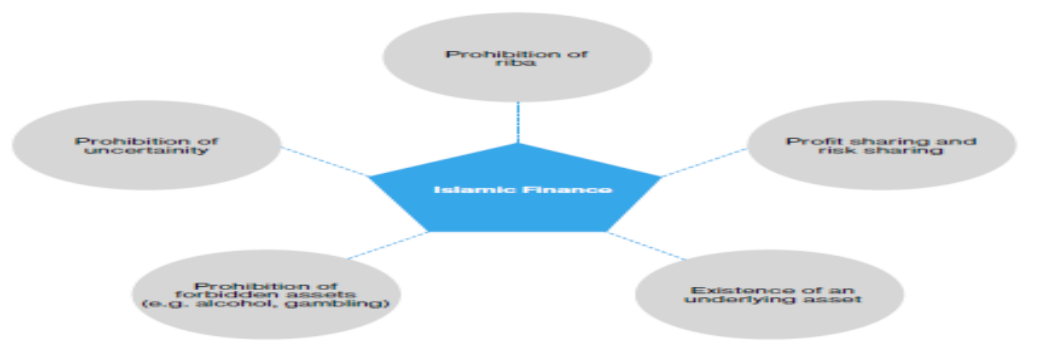

Since the initial launch in July 2009, the course was structured as combination 2 or 3 modules (Foundation modules, Core Modules and Elective Modules) depending on the background of applicants.

\begin{tabular}{|c|c|c|}
\hline \multicolumn{2}{|c|}{ Master of Islamic Banking and Finance (MIBF) } \\
Old curriculum
\end{tabular}




\begin{tabular}{|c|c|c|}
\hline $\begin{array}{l}\text { Principles of } \\
\text { Finance } \\
\text { [FIN5POF] }\end{array}$ & $\begin{array}{c}\text { Islamic Jurisprudence } \\
\text { [LAW5IJL] }\end{array}$ & $\begin{array}{c}\text { Islamic Commercial Law } \\
\text { [LAW5CLI] }\end{array}$ \\
\hline $\begin{array}{l}\text { Principles of } \\
\text { Economics } \\
\text { [ECO5POE] }\end{array}$ & $\begin{array}{c}\text { Islamic Capital Markets } \\
\text { [FIN5CAP] }\end{array}$ & $\begin{array}{l}\text { Islamic Banking } \\
\text { [FIN5BNK] }\end{array}$ \\
\hline $\begin{array}{l}\text { Accounting for } \\
\text { Managers } \\
\text { [ACC5AFM] }\end{array}$ & $\begin{array}{l}\text { Islamic Insurance } \\
\text { [FIN5INS] }\end{array}$ & $\begin{array}{c}\text { Elective } \\
\text { Unit from Master of } \\
\text { Financial Analysis } \\
\text { (LMFA) or approved by } \\
\text { School } \\
\end{array}$ \\
\hline $\begin{array}{l}\text { Statistics for } \\
\text { Business \& } \\
\text { Finance } \\
\text { [ECO5SBF] }\end{array}$ & $\begin{array}{l}\text { Elective } \\
\text { Unit from LMFA or } \\
\text { approved by School }\end{array}$ & $\begin{array}{c}\text { Elective } \\
\text { Unit from LMFA or } \\
\text { approved by School }\end{array}$ \\
\hline
\end{tabular}

In 2011, the curriculum was restructured to make it better align with the curriculum of Master of Financial Analysis (MFA) by the inclusion of compulsory subjects in order to create more opportunity for the students to obtain a double degree in MIBF and MFA. That characteristic of the course potentially attracts more international students with an international accreditation and collaboration of IF with Ethica Dubai, CFA and GARP linkage.

\begin{tabular}{|c|c|c|}
\hline \multicolumn{2}{|c|}{ Master of Islamic Banking and Finance (MIBF) } \\
New curriculum \\
\hline Part one & \multicolumn{2}{|c|}{ Part two } \\
\hline $\begin{array}{c}\text { Foundation } \\
\text { Module }\end{array}$ & Core Module & Elective Module \\
\hline $\begin{array}{c}\text { Principles of } \\
\text { Finance } \\
\text { [FIN5POF] }\end{array}$ & $\begin{array}{c}\text { Islamic Banking } \\
\text { [FIN5BNK] }\end{array}$ & $\begin{array}{c}\text { Elective } \\
\text { Unit from Master of } \\
\text { Financial Analysis (LMFA) } \\
\text { or approved by School }\end{array}$ \\
\hline $\begin{array}{c}\text { Principles of } \\
\text { Economics } \\
\text { [ECO5POE] }\end{array}$ & $\begin{array}{c}\text { Islamic Capital Markets } \\
{[\text { FIN5CAP] }}\end{array}$ & $\begin{array}{c}\text { Elective } \\
\text { Unit from LMFA or } \\
\text { approved by School }\end{array}$ \\
\hline $\begin{array}{c}\text { Accounting for } \\
\text { Managers } \\
\text { [ACC5AFM] }\end{array}$ & $\begin{array}{c}\text { Islamic Commercial Law } \\
\text { [LAW5CLI] }\end{array}$ & $\begin{array}{c}\text { Elective } \\
\text { Unit from LMFA or } \\
\text { approved by School }\end{array}$ \\
\hline $\begin{array}{c}\text { Statistics for } \\
\text { Business \& Finance } \\
\text { [ECO5SBF] }\end{array}$ & $\begin{array}{c}\text { Islamic Insurance } \\
\text { [FIN5INS] }\end{array}$ & $\begin{array}{c}\text { Elective } \\
\text { Unit from LMFA or } \\
\text { approved by School }\end{array}$ \\
\hline
\end{tabular}


The curriculum changes of MIBF resulted from the input and advice of the Course Advisory Board. That is a group of academic professionals and industrial experts such as David Kingsley, director from Kuwait Finance House (KFH). Other members of the committee are: Imran Lum, director Islamic capital Market of the National Australia Bank (NAB), MCCA and other rep from banking and finance industry, Australian Government rep, Law and accounting firms rep Asad Ansari (????), Maria (Pearson Law) and community leader rep, Hyder Gulam (President of Islamic Council of Victoria). All these representatives contributed to the main unique feature of the course which integrates perspectives on IF with CF. SO that MIBF graduates can be well placed in Australian finance job market.

During the last class of each main topic, professional representatives are invited to give a professional talk to MIBF students. It serves as a good opportunity for students to learn the real life experience and relate and question for the updated Islamic market. Approximately $60 \%$ of the guest speakers have been from financial institutions including the four major banks, $30 \%$ from government bodies and Shariah experts in IF (KFH, MCCA) and 10\% from international corporations. These guest speakers provide authentic learning experiences for students and choose qualified graduates for their internship program which helps students transfer theory into practice and consolidate learning which later leads to jobs for our graduates. Students who have a bachelor degree and 6.5 IELTS or an equivalent level of TOEFL are eligible to apply for the course.

Duration of the course depends on the prior learning and experience of the students. The chart below explains our selection criteria.

\begin{tabular}{|l|c|c|}
\hline \multicolumn{1}{|c|}{ Prior Learning and Experience } & Required Modules & Course Duration \\
\hline $\begin{array}{l}\text { Three - year Bachelors degree in an } \\
\text { area other than finance, accounting or } \\
\text { economics }\end{array}$ & $\begin{array}{c}\text { Foundation Module and } \\
\text { Core Module }\end{array}$ & 18 months \\
\hline $\begin{array}{l}\text { Three - year Bachelors degree in } \\
\text { finance, accounting or economics }\end{array}$ & $\begin{array}{c}\text { Core Module and } \\
\text { Elective Module }\end{array}$ & 18 months \\
\hline $\begin{array}{l}\text { Three - year Bachelor' degree in } \\
\text { relevant area and two years relevant } \\
\text { experience, advanced standing granted } \\
\text { for Elective Module }\end{array}$ & Core Module \\
\hline $\begin{array}{l}\text { Four - year Bachelor's degree with } \\
\text { honours in finance, accounting or } \\
\text { economics or completion of LMFA, }\end{array}$ & Core Module & 12 months \\
\hline
\end{tabular}


advanced standing granted for Elective Module

\subsubsection{Procedure of acquiring course approval}

Australian Government's Department of Education, employment and workplace relation maintained a list of approved courses in the country. They register each course under Commonwealth register of Institutions and courses for overseas students (CROCOS) and allocate specific CRICOS number to monitor the quality of the courses each institute may offer. At La Trobe University, the new course approval structure is given below.

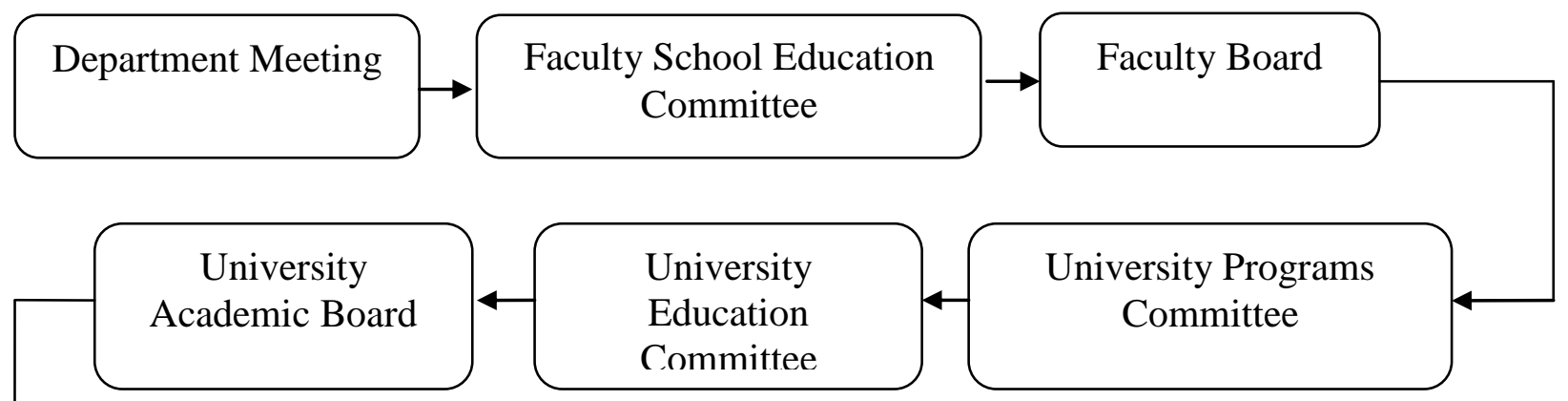

Approval of Australian

Government Department of

Education and CRICOS

Registration

\subsubsection{Marketing image}

MIFB of La Trobe University can be considered as an unprecedented master course in Australia with a full program consistent with Shariah compliant principles which are stated in Quran. It is advertised with the unique statement "An international Master degree for students wanting to study for an internationally recognized qualification in IF". MIBF is the branded name of La Trobe. It's a flagship course.

Due to a severe shortage of well-trained human capital in the IF industry in Muslim countries, MIBF targets students from GCC, Malaysia, Indonesia, second generation Australian, European, North American Muslims, and the western-financial experts who are going to seek a global recognition to capitalize on IF. The course and related course are increased in the value due to accreditation form well-known Islamic academic organization such as AAOIFI (Accounting and Auditing Organization for Islamic Financial Institutions). That results in undergraduates receiving a globally recognized certificate in IF.

Tireless efforts of academic staff and straightforward strategy have been contributing to the success of the unique MIBF marketing campaign. With the key word "Master of Islamic 
Banking and Finance, La Trobe University", more than 19900 results can be found in Google window. Moreover, Islamic Banking resulted 55, 500 while Islamic Finance is 22, 700. One of the most noticeable qualities in the launch of MIBF and IFPD courses are the application of new communication technology. Facebook, Linkade and iTunes has been used at University to record many of the talks presented during the symposium and thereafter by professional body members and visiting guest speakers from the industry. For example iTUNE download site is given below.

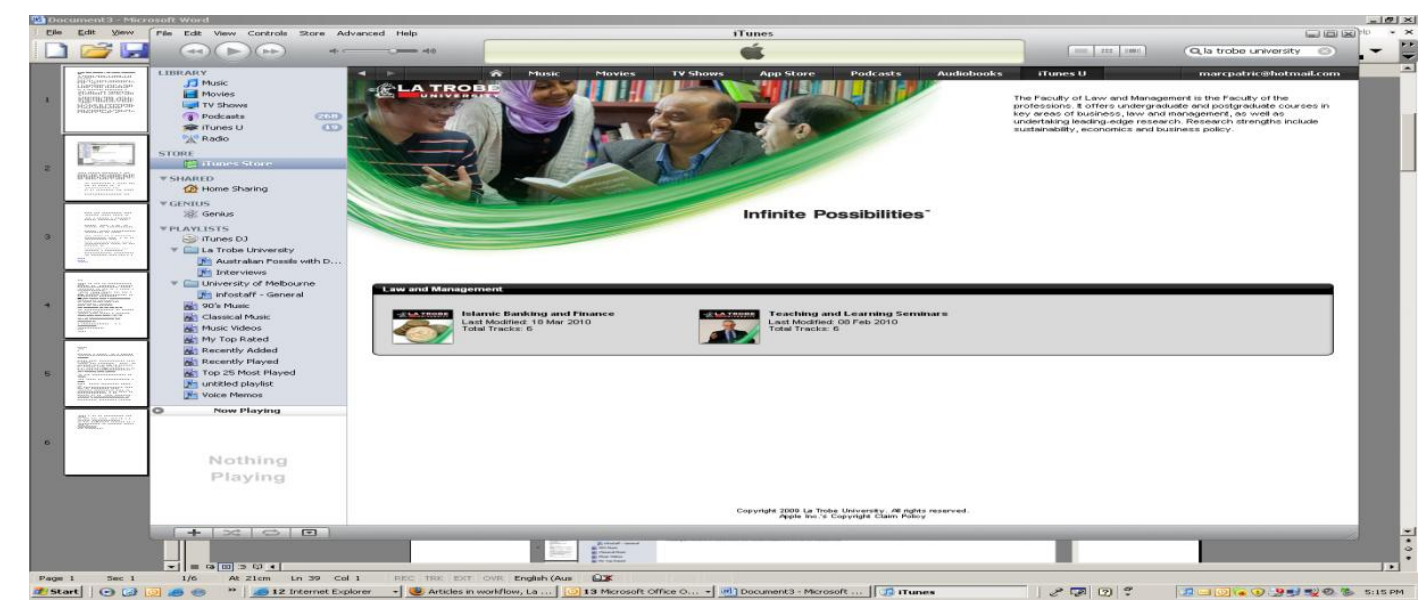

\subsection{Islamic Finance Professional Development (IFPD) course}

\subsubsection{Rationale of the course}

An online course has been structured to fulfil the demand of audiences who simply want to know the core nature and operation of IF. In light of that, audience can be international students who are searching for an appropriate course in the industry or local members of the business community who would like to obtain a primary awareness of IF to make business decisions about this new sector of the world finance structure.

\subsubsection{Online course}

As stated, IFPD can be considered as a introductory course for MIBF. By finishing the online course, graduates are equipped with comprehensive principles of IF. From that experience, a decision to start further academic study in the sector can be made. The course covers the key principles underlying IF: Modes of IF such as Islamic leasing (Ijarah); Islamic investment (Mudarabah); Cost-Plus Financing (Murabaha): Partnerships (Musharakah); Islamic Forward Selling and Manufacturing Contracts (Salam and Istisna'), and; Islamic Securitisation $(S u k u k)$. Other topics include: Global Development of IF; Challenges for 
Islamic Financial Providers; Opportunities in Australia (Government policies and tax reforms); Islamic Capital Markets; Islamic Insurance (Takaful) and Islamic Banking Products

The curriculum of the course IFPD is designed to follow the standards of AAOIFI (Accounting and Auditing Organisation for Islamic Financial Institutions) and is accredited by Ethica Institute of IF -the world most recognized IF certifier - delivering standardized e-Learning IF training and certification to professionals and students around the world. When finishing the course by sitting in a standardized online exam, the graduates are granted a certificate from Ethica CIFE ${ }^{\mathrm{TM}}$. The structure of IFPD course is appended in this paper.

\subsection{Proposed pathway to obtain MIBF with existing course}

Due to flexibility on MIBF curriculum design and its consistency with MFA, students with finance and business background can be offered different combinations between the courses to continue their academic studies. This attractive property of curriculum design resulted in remarkable benefit in time-saving for students. The average number of students involves in the course is projected to be growing in the coming period. However, still we're going through learning process to understand highly demanded time period to launch a course to attract maximum number of students. Also, we're looking into revising the fees structure and extending this successful experience to other areas of business and finance within the business faculty and beyond. Professor John Rosenberg, the senior DVC and Vice President of the University is keen in extending this into other faculties across the La Trobe University.

\subsubsection{For applicants with an undergraduate university degree}

Students who have already completed a University degree may enrol in the six-week IFPD course. Those who choose to continue into the Master of Islamic Banking \& Finance at La Trobe University receive a one elective subject exemption. 


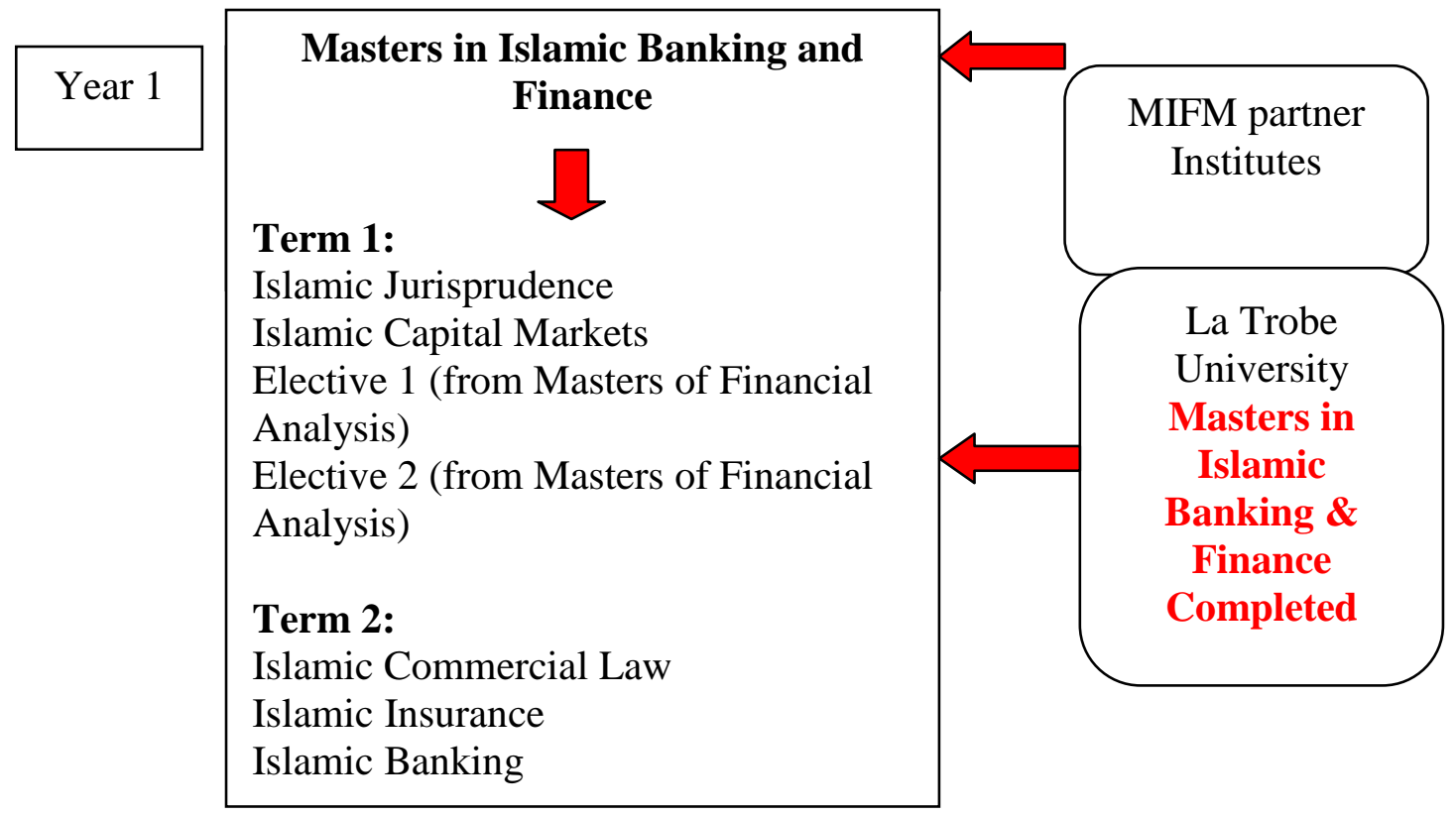

\subsubsection{For existing postgraduates with Master of Financial Analysis (MFA) Degree}

Students in the MFA course (or students who have already completed the course) are completely able to apply for an additional degree of Master of Islamic Banking and Finance resulting in a double degree. The structure of such students is given below.

\begin{tabular}{|c|c|c|c|}
\hline Term 1 & \multicolumn{2}{|c|}{$\begin{array}{l}\text { Four foundation subjects based on principles of } \\
\text { finance, economics, accounting and quantitative } \\
\text { analysis methods }\end{array}$} & Master of \\
\hline Term 2 & $\begin{array}{l}\quad \text { Core subjects } \\
\text { Debt Securities } \\
\text { Econometrics }\end{array}$ & $\begin{array}{l}\text { Elective subjects } \\
2 \text { Units from LMFA or } \\
\text { approved by School }\end{array}$ & $\begin{array}{l}\text { Analysis } \\
\text { Finished }\end{array}$ \\
\hline Term 3 & $\begin{array}{l}\text { Core subjects } \\
\text { Derivative securities } \\
\text { Portfolio management }\end{array}$ & $\begin{array}{l}\text { Elective subjects } \\
2 \text { Units from LMFA or } \\
\text { approved by School }\end{array}$ & \\
\hline
\end{tabular}




\begin{tabular}{|l|l|}
\hline Term 4 & $\begin{array}{l}\text { Core subjects of Masters in Islamic Banking and } \\
\text { Finance }\end{array}$ \\
& \begin{tabular}{l}
\multicolumn{1}{c}{ Islamic Commercial Law } \\
Islamic Insurance \\
Islamic Banking \\
Islamic Capital Markets
\end{tabular} \\
\hline
\end{tabular}

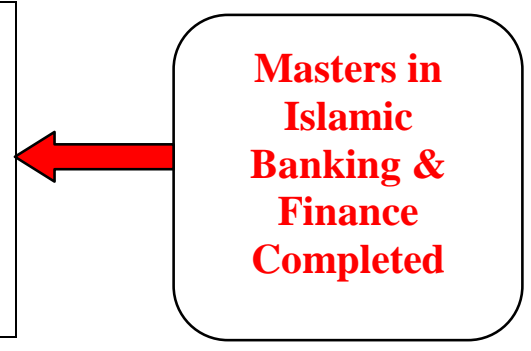

\subsubsection{For existing postgraduates with Master of Accounting and Financial Management (MAFM) Degree}

Students who are enrolled in La Trobe's Master in Accounting and Financial Management are eligible to continue one addition term to achieve a second master degree in Islamic Banking and Finance. This pathway enriches accounting postgraduates' knowledge on the principles and operation of the new sector of finance. Students will be exposed with integration between the concepts of conventional finance and accounting with IF. This represents a great opportunity for accounting students who can obtain an internationally accreditation from reliable global Islamic Academic Institutes as well as skills and techniques to work with new financial products emerging. A comprehensive structure for 2.5 years program is presented in a diagram below.

\begin{tabular}{|l|l|}
\hline Term 1 & $\begin{array}{l}\text { Four foundation subjects based on principles of } \\
\text { finance, economics, accounting and quantitative } \\
\text { analysis methods }\end{array}$ \\
\hline Term 2 & $\begin{array}{l}\text { Commercial Law } \\
\text { Financial Accounting Information System } \\
\text { Management and Cost Reporting } \\
\text { Taxation }\end{array}$ \\
\hline Term 3 & $\begin{array}{l}\text { Advanced Accounting Issues } \\
\text { Auditing and Assurance Services } \\
\text { Company and Finance Law } \\
\text { Corporate Reporting }\end{array}$ \\
\hline Term 4 & \multicolumn{1}{|c|}{ Four MFA subjects } \\
\hline
\end{tabular}

Master of Accounting and Finance Management Finished 


\begin{tabular}{|l|l|}
\hline & $\begin{array}{l}\text { Financial statement analysis } \\
\text { Derivatives securities } \\
\text { Debt securities } \\
\text { Equity securities }\end{array}$ \\
\hline Term 5 & $\begin{array}{l}\text { Core subjects of Masters in Islamic Banking and } \\
\text { Islamic Commercial Law } \\
\text { Islamic Insurance } \\
\text { Islamic Banking } \\
\text { Islamic Capital Markets }\end{array}$ \\
\hline
\end{tabular}

Masters in Islamic Banking \& Finance Completed

\section{The development of Islamic Finance education at La Trobe University}

With the successful launch of Master of Islamic Banking and Finance (MIBF) in 2009, La Trobe University has been a pioneer in developing the education for a special industry in Australia. That degree has continued to contribute to development of the academic foundation for IF and will continue to enhance the marketing of Australia as a financial hub in the Asia-Pacific region. Following the success, a series of combination course has been implemented which are designed to lead to a gradual increase in number of student enrolments.

\section{Student enrollments in 2009-2012}

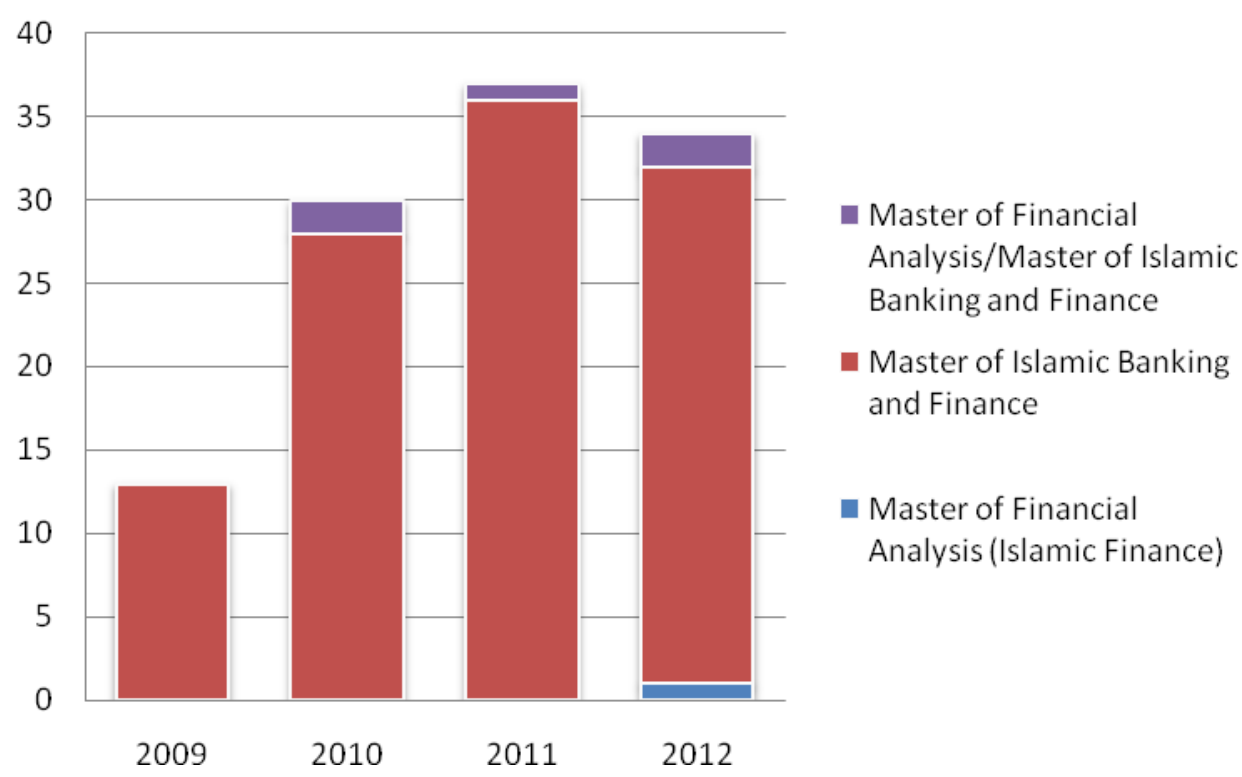

At the time of reporting, the number of enrollments in 2012 is incomplete. We can expect an addition to the figure of 2012. In line of this, figure in 2009 was just collected for the second semester. Over four years, La Trobe University has an average of approximate 28 
students enrolled into IF study with a standard deviation change of 9 students from the average number for a given year or volatility of 9 students up and down in numbr of enrolment per year which seems pretty volatile in generating revenues. IN dollar terms it's a gain or loss of $\$ 360$, 000 per year which equivalent to 3 full time staff salary. So, its very important to market in such a way to avoid any future loss in generating revenues for the university.

Moreover, throughout the years, an approximate growth of $37.78 \%{ }^{13}$ can be observed. Especially, in 2010 and 2011, there was significant increase at $130 \%$ and $23.3 \%$ respectively. That is understandable because of full-year recognition of 2010 and 2011 student enrolments. Those signify a sustainable growth in the need of academy for the industry as long as the marketing campaign is effective and quality of education maintained and expert staff is retained.

The pie chart below illustrates the average weights of a variety of IF course. That shows a growing diversification in course choice and a flexible combination between related courses. In details, MIBF still plays an important role which accounts for $91 \%$ in the total number of IF students. It is also shown co-efficient of variation in the number of students involving. It is $36.67 \%$ higher than $34.6 \%$ of the Double Master degree program. It indicates a greater change in number of MIBF students may impose a remarkable impact on structure of Islamic Banking and Finance education.

\title{
Average weights fo Islamic Finance courses in La Trobe University
}

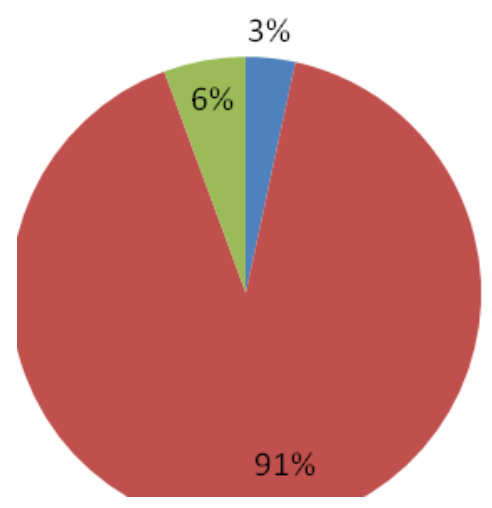

\author{
Master of Financial \\ Analysis (Islamic Finance) \\ Master of Islamic Banking \\ and Finance \\ Master of Financial \\ Analysis/Master of Islamic \\ Banking and Finance
}

\footnotetext{
${ }^{13}$ The growth $37.78 \%$ numbers are calculated using Geometric Mean, the way we use in finance literature.
} 


\section{Islamic Finance students in term of nationality}

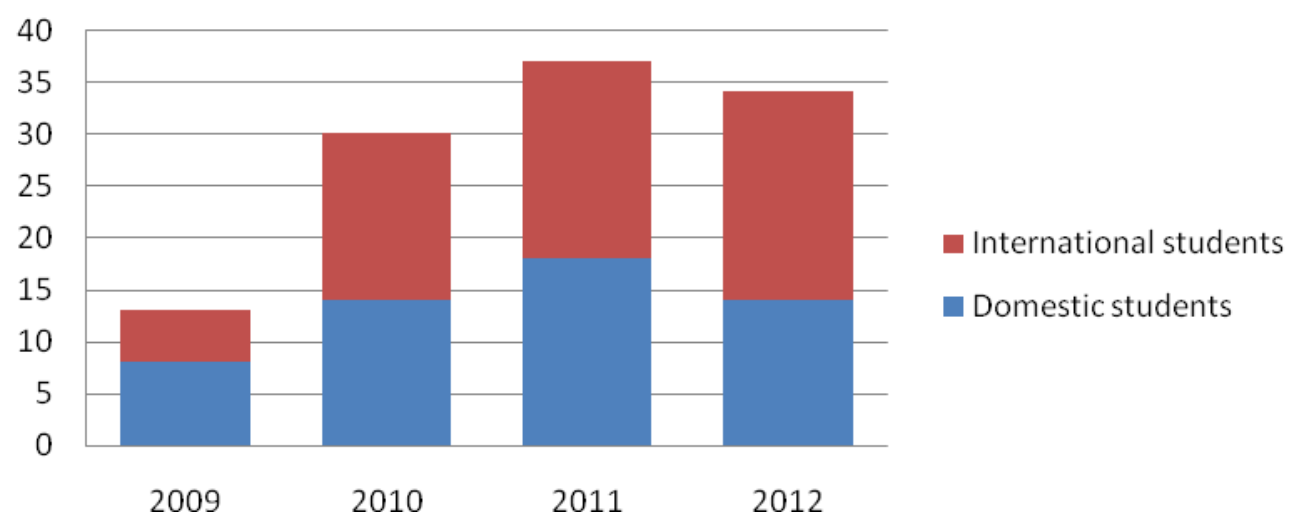

Along with an increase in the number students, there is a growth in international segment. However, as shown in the chart above, number of domestic students still outweighs the international ones with the exception of 2012 numbers. The average of students for the period 2009-2012 is 14 (domestic) 15 (overseas). However, coefficient of variation in given figures that show volatility in enrolment is $26.44 \%$ in domestic segment and $39.72 \%$ in international segment. That demonstrates a more stable increase in the need of domestic graduates for IF study. Nonetheless, with an annually growing increase in international enrolments, it can be projected that there will be an increasing interest and demand from offshore countries with a robust internationally-based marketing campaign. 


\section{Number of domestic students in term of unit}

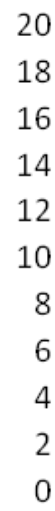

20
18
16
14
12
10
8
6
4
2
0

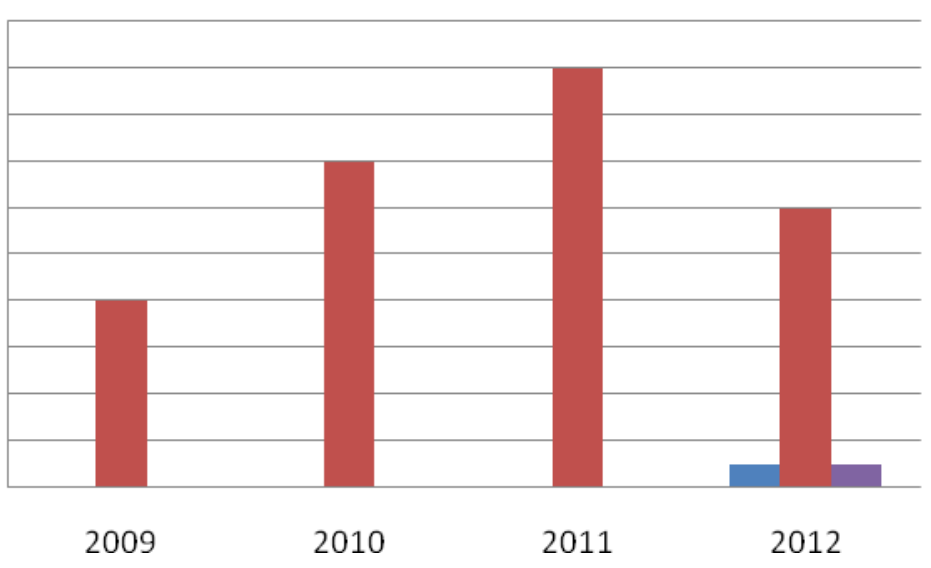

- Master of Financial Analysis (Islamic Finance)

Master of Islamic Banking and Finance

- Master of Financial Analysis/Master of Islamic Banking and Finance

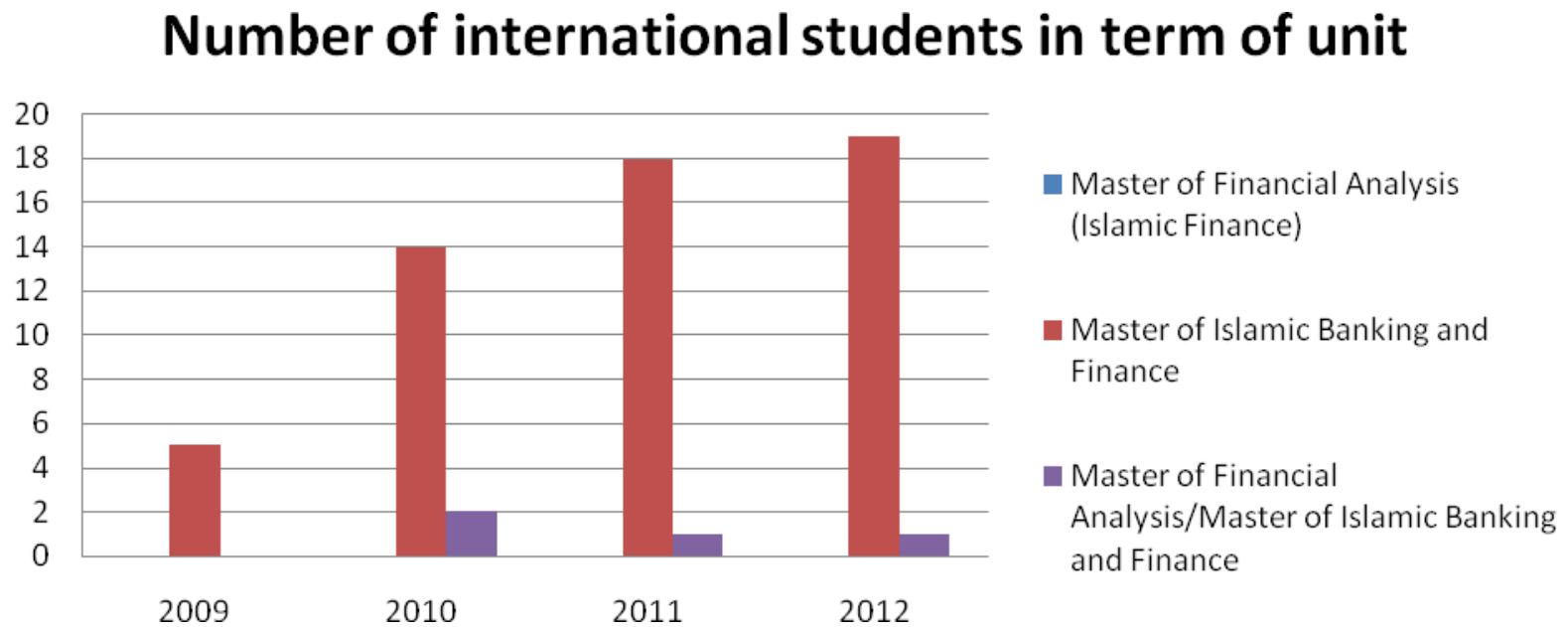

The attraction of the course is also illustrated by the gender structure of participants. In experience of the first half of 2012, 30 per cent are female, whereas, this figure is 70 per cent for male in the total number of students. The structure stays the same for both domestic segment and international segment. It reflects the increasing interest in all genders in the arising finance sector. Moreover, it signifies desired involvement of women in Islamic banking and finance in which the men still play a dominant role. Therefore, a special marketing campaign should be taken into account to encourage participation of females by which the gender equality can be improved. 


\section{Gender group of MIBF graduates 2012}

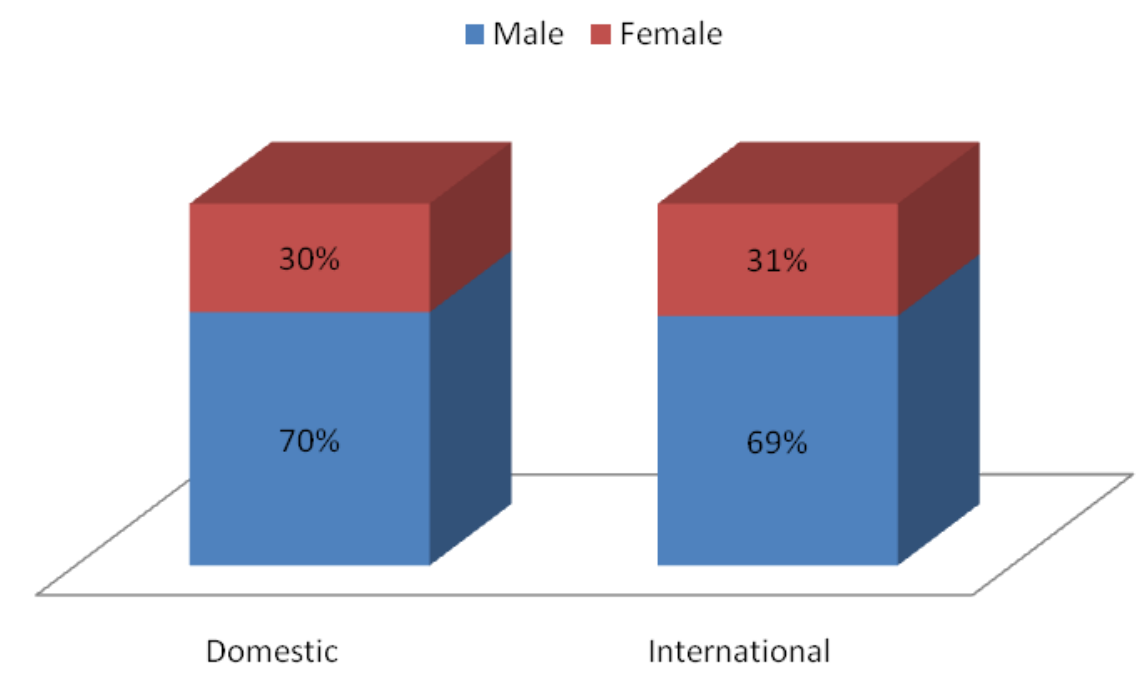

In term of age groups, $70 \%$ of the participants are from 20-29 years old. That is a good signal for the course as well as the industry. Notably, $92 \%$ of international students fallin this lage range. The majority of the age groups suggests the interest of the young generation with purpose of enhancing academic knowledge about Islamic fiance. Accordingly, it can be claimed that an active human capital with professional skills and expert understanding has been prepared for the official launch of IF industry in Australia. It serves the national strategy to develop an Islamic capital market for commodities and infrastructure, and import capital from Pacific region such as ASEAN, APEC and Middle East countries.

\section{Age group of MIBF graduates 2012}

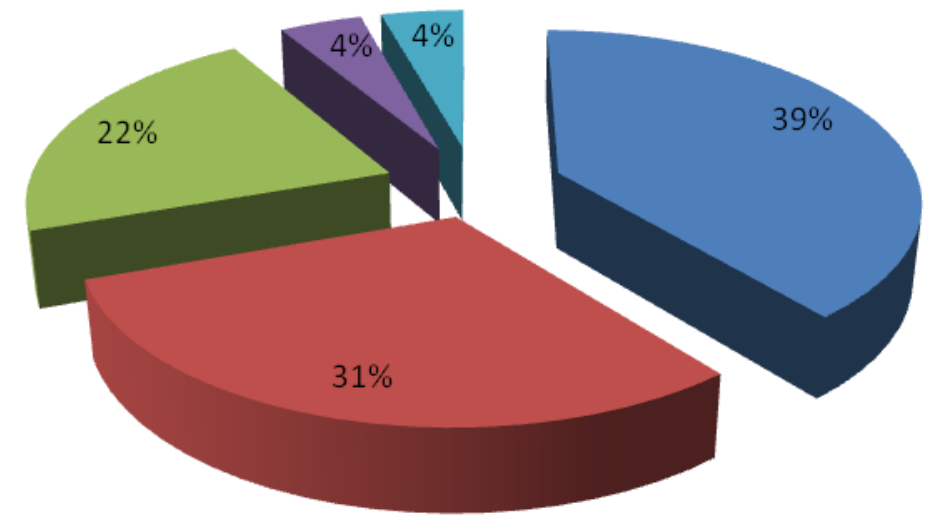

$-20-24$ Years
$-25-29$ Years
$-30-39$ Years
$-40-49$ Years
$-50-59$ Years 


\section{Domestic}

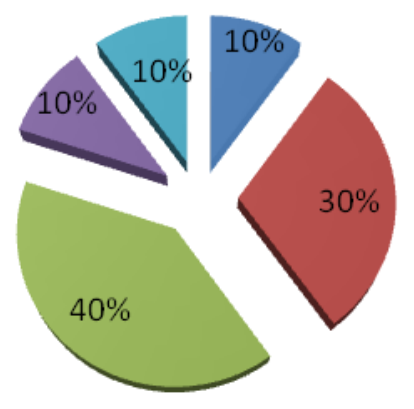

\section{International}

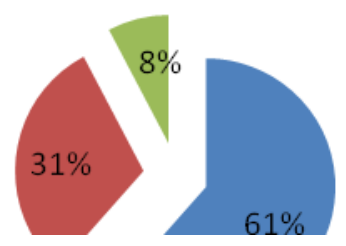

IFPD online short course was officially launched in 2011 with initial purpose to provide students and graduates a fundamental basis of IF and its principles within a 6-week course. In January 2011, there were 27 students enrolled. However, the number of participants fell over 3 courses to 6 in February 2012 and then picked up in June session to 16. This is a learning curve for a Director to understand what month, year or time a particular session may be offer to attract maximum students and trainees to be benefited. However, IFPD course is estimated to attract 50 students in last year, earning some extra revenue for the University. The fall in may be due to the common effect of the decrease in number of international student enrolments in 2010-2011 as reported by Australian Bureau of Statistics $(2011)^{14}$.

In IFPD course it was interesting to observe that 60 per cent of the audience were local and other 40 per cent from offshore venues to access the course. That mean they miss out face-to-face session and will attempt to access via live webinars conducted by instructor in-charge. It also suggests that there should be a robust marketing campaign to raise a strong awareness about the course at both local and in the international segment. If this compaign is done more professionally then the students enrolments will rise for future IFPD sessions. The number of participants in IFPD course showed a strong interest in taking up MIBF, MFA and/or MFM or the combination of double degrees. The graph below shows the last four session enrolment trend in our IFPD course.

\footnotetext{
${ }^{14}$ Australian Bureau of Statistics, 4102.0 - Australian Social Trends, Dec 2011
} 


\section{Islamic Finance Professional Development (IFPD) course}

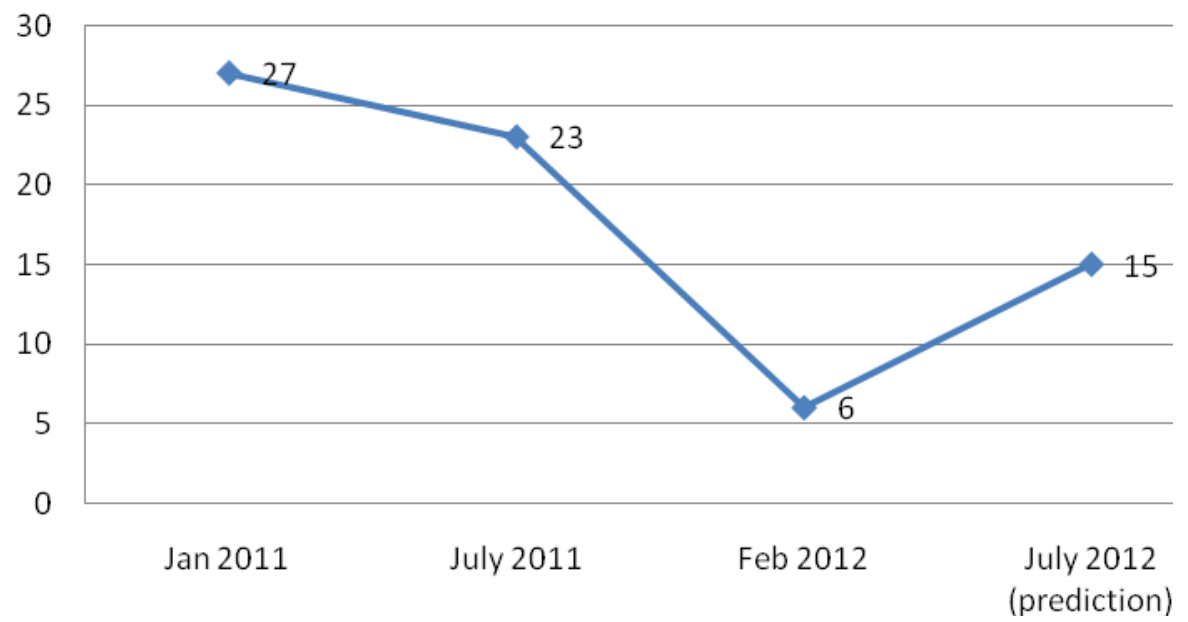

\section{IF Academic staff achievements over the 4 year period}

Throughout 4 years, La Trobe academic staff in IF education has achieved many precious experiences in developing teaching techniques, curricula design and materials. That is reflected in the academic results of students from four core subjects: Islamic Banking (FIN5BNK), Islamic Capital Market (FIN5CAP) and Islamic Commercial Law (LST5CLI), Islamic Insurance (FIN5INS).

It is reported that $96 \%$ of graduates pass the subjects with approximately $60 \%$ categorized as $\mathrm{A}$ and $\mathrm{B}$ grades while others got $\mathrm{C}$ or D grades. Only $4 \%$ failed and/or dropped out. These findings are in line with other finance courses at La Trobe. It may be due to the new exposure of students to the concept of IF. Noticeably, graduates who took Islamic Banking subject - FIN5BNK as an elective, $100 \%$ pass with approximately $64 \%$ of A and B grades and the rest $\mathrm{C}$ and $\mathrm{D}$. Moreover, this subject has been also attracting more students compared to other MIBF subjects. This may be its an elective subject for other Masters degrees within the faculty and in the faculty of arts and humanities. This is flexible combination with the CFA qualifications which gives the students accreditation in IF as well as a shortcut to achieving a double degree. The pie chart below shows the grades distribution of FINFBNK subject. Also, the students satisfaction with this subject is more than the average across the whole faculty and Lecturer in charge of the subject is national award winner of 2010 citation award and the University and the faculty teaching award 2010, 2009, respectively. 


\section{Average academic record for Islamic Finance Unit}

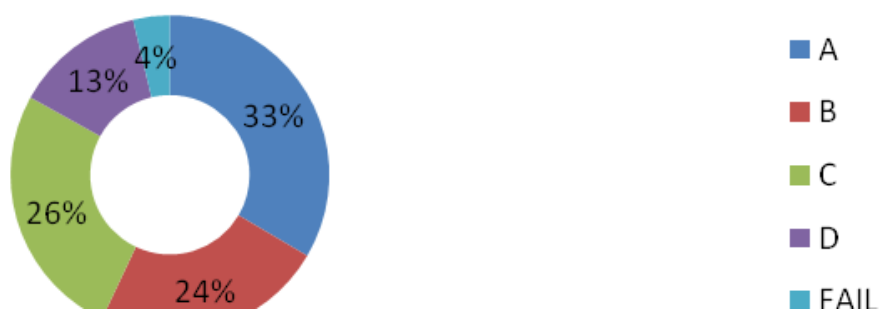

Since the launch in 2009, five graduates completed Master degree in Islamic Banking and Finance in 2010. This figure is 17 in 2011. The average mark is 70.29\% in 2010 and in $64.61 \%$ in 2011 . The decrease in the mark of 2011 may be due to a drop in a quality of domestic graduates, as can be observed in the graph below. However, the quality of international students has increased slightly from $65.08 \%$ to $66.29 \%$. These results are an optimistic sign that the quality of curricula in IF education is suitable for international training.

\section{MIBF Graduates}

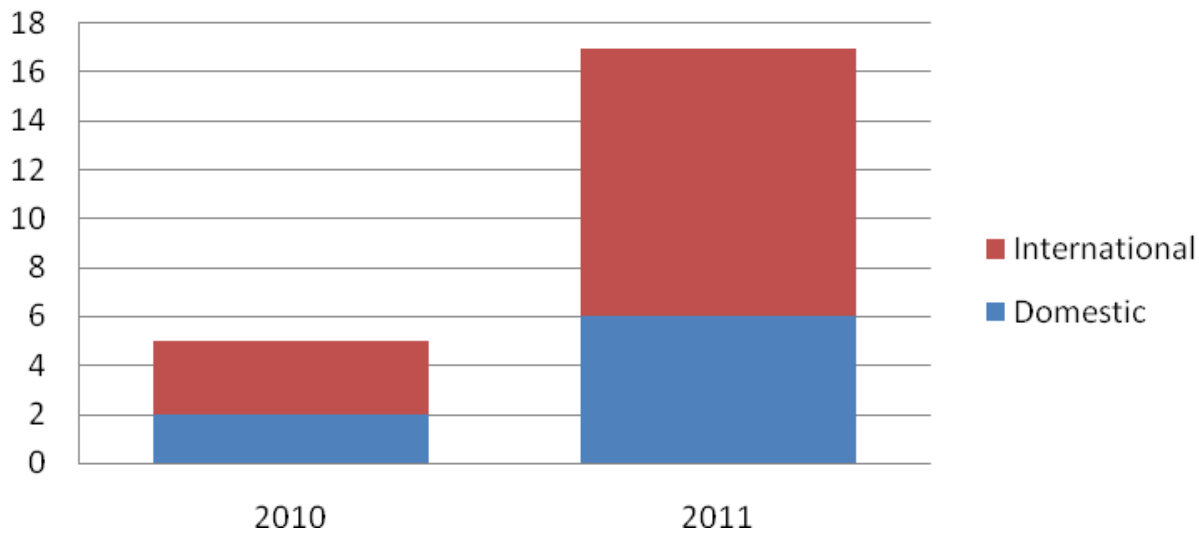




\section{Weighted Average Mark of MIBF}

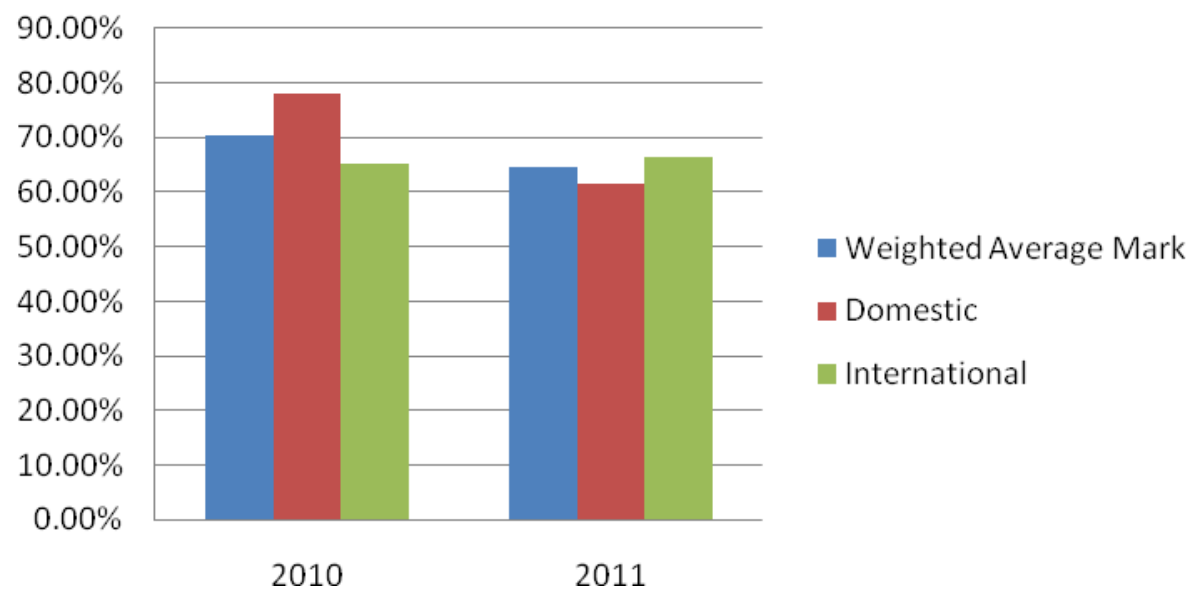

\section{Industry Feedback:}

The career outcomes for a sample of 15 students who graduated from MIBF in current years is demonstrated in the chart below:

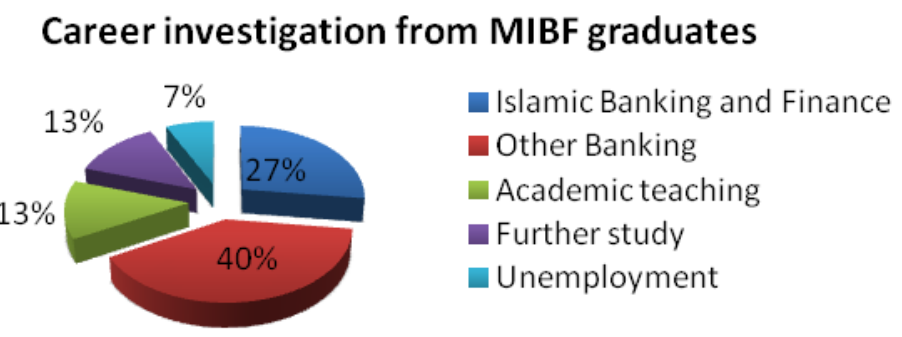

As interpreted from the chart, approximately $67 \%$ of the graduates are involving in the finance industry and nearly $27 \%$ are working for IF banks and institution in offshore countries, especially in Malaysia and Middle East. This suggests that Banking and Finance industry may prefer graduate students who took MIBF course from La Trobe University.

However, there are still $7 \%$ of the graduates unemployed. The number indicates that there is lesser unemployment for IF graduates because IF is relatively far smaller than CF industry. IF in Australia has been under discussion at government levels for a number of years. An official launch is anticipated when legal regulations are available. There will be probably more demands for human capital in IF to build up the industry, which will serve the national strategy to be capital-importing country.

\section{Forecasting enrolments}

To predict students' enrolments for the next period, a regression model between year and historical record has been built up. The statistics are calculated based on SPSS as follows: 


\section{Model Summary ${ }^{\text {b }}$}

\begin{tabular}{|c|c|c|c|c|c|c|c|c|c|c|}
\hline \multirow[b]{2}{*}{$\begin{array}{c}\text { Mod } \\
\text { el }\end{array}$} & \multirow[b]{2}{*}{$\mathrm{R}$} & \multirow[b]{2}{*}{$\begin{array}{c}\text { R } \\
\text { Squar } \\
\mathrm{e}\end{array}$} & \multirow[b]{2}{*}{$\begin{array}{c}\text { Adjuste } \\
\text { d R } \\
\text { Square }\end{array}$} & \multirow{2}{*}{$\begin{array}{c}\text { Std. } \\
\text { Error of } \\
\text { the } \\
\text { Estimate }\end{array}$} & \multicolumn{5}{|c|}{ Change Statistics } & \multirow[b]{2}{*}{$\begin{array}{l}\text { Durbin- } \\
\text { Watson }\end{array}$} \\
\hline & & & & & $\begin{array}{c}\text { R } \\
\text { Square } \\
\text { Change }\end{array}$ & $\begin{array}{c}\mathrm{F} \\
\text { Change }\end{array}$ & df1 & df2 & $\begin{array}{l}\text { Sig. F } \\
\text { Change }\end{array}$ & \\
\hline 1 & .843 & .710 & .565 & 7.07107 & .710 & 4.900 & 1 & 2 & .157 & 2.000 \\
\hline
\end{tabular}

a. Predictors: (Constant), date

b. Dependent Variable: enrolment

\begin{tabular}{|c|c|c|c|c|c|c|c|}
\hline \multirow{2}{*}{ Model } & \multicolumn{2}{|c|}{$\begin{array}{l}\text { Unstandardized } \\
\text { Coefficients }\end{array}$} & \multirow{2}{*}{$\begin{array}{c}\begin{array}{c}\text { Standardized } \\
\text { Coefficients }\end{array} \\
\text { Beta }\end{array}$} & \multirow{2}{*}{$\mathrm{t}$} & \multirow{2}{*}{ Sig. } & \multicolumn{2}{|c|}{$\begin{array}{l}95.0 \% \text { Confidence } \\
\text { Interval for B }\end{array}$} \\
\hline & B & $\begin{array}{l}\text { Std. } \\
\text { Error }\end{array}$ & & & & $\begin{array}{l}\text { Lower } \\
\text { Bound }\end{array}$ & $\begin{array}{l}\text { Upper } \\
\text { Bound }\end{array}$ \\
\hline (Constant) & 11.000 & 8.660 & & 1.270 & .332 & -26.262 & 48.262 \\
\hline Date & 7.000 & 3.162 & .843 & 2.214 & .157 & -6.606 & 20.606 \\
\hline
\end{tabular}

\begin{tabular}{|c|c|c|c|c|c|}
\hline & Mesiduals Statistics & \\
\hline & Maximum & Maximum & Mean & $\begin{array}{c}\text { Std. } \\
\text { Deviation }\end{array}$ & $\mathrm{N}$ \\
\hline $\begin{array}{c}\text { Predicted } \\
\text { Value } \\
\text { Residual } \\
\text { Std. }\end{array}$ & 18.0000 & 39.0000 & 28.5000 & 9.03696 & 4 \\
$\begin{array}{c}\text { Predicted } \\
\text { Value } \\
\text { Std. } \\
\text { Residual }\end{array}$ & -1.162 & 1.162 & .000 & 1.000 & 4 \\
\hline
\end{tabular}

a. Dependent Variable: enrolment

The regression model can be written as:

Future enrolment $=11+7 *$ i-th Year

Based on the regression model, we can estimate the upcoming IF students in 2013, 2014, 2015, 2016

2013: $11+7 * 5=46$

2014: $11+7 * 6=53$

2015: $11+7 * 7=60$

2016: $11+7 * 8=67$

However, at the moment, the course is still in its infancy. Therefore, because of the lack of observations, the prediction cannot avoid a big deviation from the true observation. This regression can be revised in the latter period when there are more observations and more independent variables identified. 


\section{Conclusion and Remarks:}

The world has witnessed an increasing growth in IF industry since its establishment in 1940s to GFC of 2008 around the globe. Although the industry has accounted for approximately $2.7 \%$ of global financial transactions, it is believed that the continual growth will be $10 \%-15 \%{ }^{15}$. Due to nature of the IF industry which has contributed positively to the real economic activities in commodity markets, agro based industry, ethically responsible financial transaction, and publically funded infrastructure construction projects. In Australia, the federal and state government are discussing how to draft official legislation framework which can be in development IF industry in Australia. This framework will support the objective of making Australia become a financial hub in Asia Pacific region. There is an essential demand for academic and technical training in this emerging sector. However, lack of consistency in standardized regulations between Islamic countries and the Muslim minorities western countries be challenging. This may create some obstacles to the expansion of IF globally. The global leading institutes like IRTI, IDB, OIC and the Islamic Economics Institute (Headed by Dr Abdullah Turkistani, formerly known as Islamic Economic Centre at KAU. In recent workshop part of the issue is addressed by Institute (Workshop papers and presentation 2012, Nov., 12-13). One of the discussions comments was to establish uniform standardized criteria in IF and a well-developed educational program may be a solution to these concerns. There needs to be a focus on developing a new generation of Islamic Economics scholars who have a comprehensive and complete knowledge about global finance as well as Islamic banking and finance and using tablets in financial transaction and knowhow of developing cloud based Islamic financial products. This could lead to the generation of a united framework for global IF standards. La Trobe University can be seen an unprecedented explorer in the industry education in Australia since the launch of IF Australia in 2009. The success at the first stage is continued with an improvement process contributed by academic staff and industrial professionals. Its advantage in curricula design has played an important role in the success of the course. The uniqueness of curricula is that it integrates the perspectives about CF and IF. La Trobe University is the first Islamic Financial Academic Institution in Australia. Its staff is ready to establish an Asia Pacific centre which allow academician and industry professionals to update and enhance IF knowledge, improve industry standards in Australasian region. The true success of the centre and the course is the development of a generation of industry experts who will actively contribute to the national strategy and the development of Global IF industry. ${ }_{15}$ Cihak, Martin; Hesse, Heiko, Islamic Banks and Financial Stability: An Empirical Analysis, IMF Working Paper, page 5,
http://www.imf.org/external/pubs/ft/wp/2008/wp0816.pdf 


\section{REFERENCE}

Australian Bureau of Statistics, 4102.0 - Australian Social Trends, Dec 2011

Austrade, Islamic Finance, 2010, Available at:

http://www.austrade.gov.au/search.aspx ?articleid=4345\&moduleid=8367\&keywords=islamic $\% 20$ finance $\&$ sitesection $=\&$ sitesectiondescr $=$

Chowdhry, S. (2010). An introductory review of the major centers and initiatives for Islamic finance education around the world, Dinar Standard, Available at:

http://www.dinarstandard.com/finance/finance_instit120604.htm, Jun 2010

Cihak, M. \& Hesse, H. (2008). Islamic Banks and Financial Stability: An Empirical Analysis, IMF Working Paper, page 5, Available at:

http://www.imf.org/external/pubs/ft/wp/2008/wp0816.pdf

Colan, A. (2012). Principles of Islamic Finance, MCCA News, Number 1, March 2012

Global Finance (2011). World Best Islamic Financial Institutions, Available at:

http://www.gfmag.com/tools/best-banks/11198-worlds-best-islamic-financial-institutions-201 $\underline{\text { 1.html\#axzz1vO6LR3a2 }}$

Kearney, A. T. (2006). Booming Islamic banking will need 30,000 jobs in the Gulf in 10 years, AMEinfo, Available at: http://www.ameinfo.com/106063.html

Khalid, K. (2009). The Global Financial Crisis and International Migration: Policy Implications for Australia, Lowy Institute for International Policy, July 2009, p. 4.

Khan, M. M. \& Bhatti, M. I. (2008). Development in Islamic Banking: A case of Pakistan, Palgrave Macmillan, UK.

Perry, F. V. \& Rehman, S. S. (2011). Globalization of Islamic Finance: Myth or Reality? International Journal of Humanities and Social Science, Vol.1, No.9, 2011.

Wikipedia, Islamic Finance, Available at: http://en.wikipedia.org/wiki/Islamic banking

Workshop Papers and Presentations. (2012). Workshop on the Future of Islamic Economics: A Call for Discussion, Workshop papers, Islamic Economics Institute, King Abdulaziz University, Jeddah, Saudi Arabia, 12-13 November, 2012.

World Bank Data, (2006). World Development Indicators, Washington D.C, USA. 